\title{
Platelet phagocytosis in the bone marrow causing thrombocytopenia in extrapulmonary tuberculosis
}

\author{
Nageswar Sahu, ${ }^{1}$ Amit Kumar Adhya (i) ${ }^{2}$
}

${ }^{1}$ Pathology, Kalinga Institute of Medical Sciences, Bhubaneswar, Odisha, India

${ }^{2}$ Pathology and Lab Medicine, All India Institute of Medical Sciences, Bhubaneswar, Odisha, India

\section{Correspondence to} Dr Amit Kumar Adhya, drakadhya@gmail.com

Accepted 13 September 2019

Check for updates

(C) BMJ Publishing Group Limited 2019. No commercial re-use. See rights and permissions. Published by BMJ.

\footnotetext{
To cite: Sahu N, Adhya AK. BMJ Case Rep 2019;12:e232172. doi:10.1136/bcr-2019232172
}

\section{DESCRIPTION}

A 58-year-old man presented with on and off fever for 1 month. He developed delirium, loss of consciousness and neck rigidity for the last 4 days. On examination, the patient had mild pallor, icterus and splenomegaly $(5 \mathrm{~cm}$ below the left costal margin). There was no lymphadenopathy. Chest and cardiovascular system examination were normal. Chest X-ray was normal. Sputum examination was negative for acid-fast bacillus (AFB). The patient was HIV and $\mathrm{HBs} \mathrm{Ag}$ seronegative. Routine Complete Blood Count showed pancytopenia (haemoglobin: $94 \mathrm{~g} / \mathrm{L}$, total leucocyte count: $0.46 / \mathrm{L}$, total platelet count: $90 \times 10^{9} /$ L). Peripheral smear showed microcytic hypochromic red blood cells. Cerebrospinal fluid analysis showed lymphocytic pleocytosis with raised adenosine deaminase enzyme level suggestive of tubercular meningitis. Bone marrow aspiration was done for pancytopenia. Marrow was normocellular with marked maturation arrest of granulocytic series. Megakaryocyte number was slightly increased. Marked platelet phagocytosis by histiocytes was noted. There was no evidence of phagocytosis of granulocytic or erythroid cells. Bone marrow biopsy revealed multiple caseating epithelioid cell granulomas with Langhan's type of giant cells (figure 1). Rod-shaped, red-coloured, slender, beaded AFB, consistent with the morphology of Mycobacterium tuberculosis, were found on Z-N stain. There was

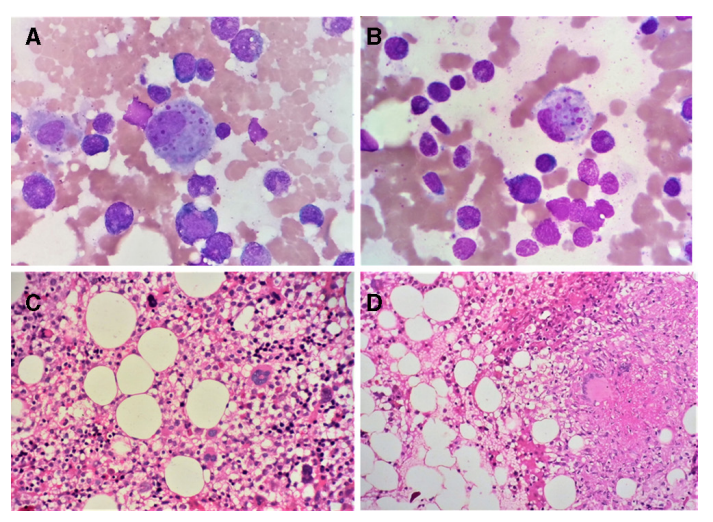

Figure $1 \quad(A, B)$ Bone marrow aspirate smear shows platelet phagocytosis by histiocytes and maturation arrest in the granulocytic series. May Grunwald Giemsa stain, 400x. (C) Bone marrow biopsy shows normocellular to hypercellular marrow spaces with adequate erythroid cell and megakaryocytes. H\&E stain, 200x. (D) Bone marrow shows caseating epithelioid cells granulomas with Langhan's giant cells. H\&E stain, 200x.

\section{Patient's perspective}

I was suffering from fever and subsequently lost consciousness and hospitalised. Doctors performed many tests and diagnosed me to be having tuberculosis. My blood cell counts were reducing day by day. My bone marrow examination was done and it was found that tuberculosis has affected my bone marrow and that was the cause of decreased cell counts in my blood. I was treated with antitubercular drugs and my condition improved. I am thankful to the team of doctors who made a timely diagnosis and cured me of my illness.

\section{Learning points}

- Tuberculosis may rarely present with thrombocytopenia.

- An important cause of thrombocytopenia in tuberculosis is phagocytosis of platelets in the bone marrow.

- Bone marrow examination must be routinely done to look for the exact pathogenesis of cytopenia in patients of tuberculosis.

minimal fibrosis surrounding the granuloma. Marked leucopenia was explained by maturation arrest in granulocytic series, and the microcytic hypochromic anaemia was attributed to concomitant iron deficiency. The CBC became normal after 3 months of treatment with antitubercular drugs.

Several factors are considered to cause cytopenias in disseminated or extrapulmonary tuberculosis including immune-mediated destruction, hypersplenism, histiocytic hyperplasia, maturational arrest, infiltration of the bone marrow by caseating or noncaseating granulomas causing reversible or irreversible fibrosis. ${ }^{1-3}$ This case highlights platelet phagocytosis as a significant contributor to peripheral blood thrombocytopenia in tuberculosis. It also emphasises the importance of trephine biopsy for the evaluation of pancytopenia in tuberculosis patients. A bone marrow biopsy may be helpful in distinguishing between various causes of pancytopenia such as antitubercular drug-induced aplastic anaemia, infection-associated haemophagocytic disorder or marrow fibrosis. Delineating the exact causes may help in guiding the therapy. 
Contributors NS was involved in the drafting of the article, acquisition of images and revising the manuscript. AKA was involved in the addition of data, analysing it, drafting the article and revising it critically for important intellectual content.

Funding The authors have not declared a specific grant for this research from any funding agency in the public, commercial or not-for-profit sectors.

Competing interests None declared.

Patient consent for publication Obtained.

Provenance and peer review Not commissioned; externally peer reviewed.

ORCID ID
Amit Kumar Adhya http://orcid.org/0000-0002-1860-4035

\section{REFERENCES}

1 Singh KJ, Ahluwalia G, Sharma SK, et al. Significance of haematological manifestations in patients with tuberculosis. J Assoc Physicians India 2001:49:790-4.

2 Avasthi R, Mohanty D, Chaudhary SC, et al. Disseminated tuberculosis: interesting hematological observations. J Assoc Physicians India 2010;58:243-4.

3 Bhargava V, Farhi DC. Bone marrow granulomas: clinicopathologic findings in 72 cases and review of the literature. Hematol Pathol 1988:2:43-50.

Copyright 2019 BMJ Publishing Group. All rights reserved. For permission to reuse any of this content visit https://www.bmj.com/company/products-services/rights-and-licensing/permissions/

BMJ Case Report Fellows may re-use this article for personal use and teaching without any further permission.

Become a Fellow of BMJ Case Reports today and you can:

- Submit as many cases as you like

Enjoy fast sympathetic peer review and rapid publication of accepted articles

- Access all the published articles

Re-use any of the published material for personal use and teaching without further permission

\section{Customer Service}

If you have any further queries about your subscription, please contact our customer services team on +44 (0) 2071111105 or via email at support@bmj.com.

Visit casereports.bmj.com for more articles like this and to become a Fellow 